\title{
Effects of methane outgassing on the Black Sea atmosphere
}

\author{
K. Kourtidis ${ }^{1}$, I. Kioutsioukis ${ }^{1}$, D. F. McGinnis ${ }^{2}$, and S. Rapsomanikis ${ }^{1}$ \\ ${ }^{1}$ Laboratory of Atmospheric Pollution and Pollution Control Engineering of Atmospheric Pollutants, Dept. of Environmental \\ Engineering, Democritus University of Thrace, P.O. Box 447, 67100 Xanthi, Greece \\ ${ }^{2}$ Surface Waters - Research and Management, Swiss Federal Institute of Aquatic Science and Technology, Eawag, 6047 \\ Kastanienbaum, Switzerland
}

Received: 7 February 2006 - Published in Atmos. Chem. Phys. Discuss.: 9 May 2006

Revised: 25 September 2006 - Accepted: 6 November 2006 - Published: 14 November 2006

\begin{abstract}
Methane in air and seawater was measured in the Eastern Black Sea during the 10-18 December 1999 BIGBLACK project cruise. The measurements allowed for the calculation of supersaturation ratios and methane fluxes across the air-sea interface. $\mathrm{CH}_{4}$ mixing ratios in air were generally in the $1.8-2.0 \mathrm{ppmv}$ range, while surface $(4 \mathrm{~m}$ depth) seawater concentrations varied from 4 to 93 ppmv. Above active seep areas, the water was supersaturated to around $500 \%$ with respect to the overlying atmosphere. Accordingly, flux densities varied greatly and were up to $3300 \mathrm{umol} \mathrm{m}^{-2} \mathrm{day}^{-1}$. In the Sevastopol harbour, supersaturations up to around $3000 \%$, similar to those at the Danube Delta, were observed, while in the Istanbul harbour supersaturations could not be determined because the very high values of water concentrations led to detector saturation. Simple modelling shows that the observed fluxes do not have any substantial impact on the methane content of the Black Sea atmosphere, as they would only raise its concentrations by less than $50 \mathrm{ppt}$. On the other hand, calculations performed as part of the CRIMEA project show that mud volcano eruptions could episodically raise the methane concentrations well above their regional background for several tens of kilometres downwind. These calculations, which also apply to mud volcano eruptions elsewhere on the globe, indicate that the spatial extend and the magnitude of the atmospheric perturbation is such that its observation might lie within the capabilities of existing satellite instrumentation such as SCIAMACHY on ENVISAT.
\end{abstract}

Correspondence to: K. Kourtidis

(kourtidi@env.duth.gr)

\section{Introduction}

Methane is an important greenhouse gas and a precursor of tropospheric ozone (e.g. IPCC, 2001; Lelieveld et al., 1993, 1998). It is produced in a variety of thermogenic and biological methanogenic processes, some of which occur on geologic time scales, while others on much shorter ones. As a result of these processes, large variations of the atmospheric methane abundance might be expected, especially if large reservoirs become unstable. Such reservoirs include methane hydrates (e.g. Kvenvolden, 1993). Another important pathway for degassing buried sediments appears to be episodic mud volcano eruptions (e.g. Dimitrov, 2002; Kopf, 2002) and continuous seepage over wide areas as well as over localised gas vents (e.g. Etiope and Klusman, 2002). Underwater seepages have been investigated by many authors in various parts of the world (e.g. Judd et al., 1997; Hornafius et al., 1999; Clark et al., 2000; Klusman et al., 2000), and have been found to result in elevated methane concentrations in the surface waters overlying these seeps (e.g. Cynar and Yayanos, 1992; Ward, 1992).

The Black Sea has received attention as a target of investigations on methane because of the large amounts of methane trapped in the anaerobic sediments and the hydrates present underneath these sediments. Under normal conditions, methane is vented from the sediments to the overlying water through seeps; some of this methane reaches the water-air interfaced unoxidised and subsequently escapes to the atmosphere, although most of it is consumed from bacterial activity within the water column (e.g. Durisch-Kaiser et al., 2005).

Some investigations of the methane flux from the Black Sea to the atmosphere have already been carried out (Amouroux et al., 2002; Schmale et al., 2005), yielding flux densities generally between 0.19$0.77 \mathrm{nmol} \mathrm{m}^{-2} \mathrm{~s}^{-1}$ (16-66 umol m${ }^{-2} \mathrm{day}^{-1}$ ), while above active seeps these might increase to $0.96-2.32 \mathrm{nmol} \mathrm{m}^{-2} \mathrm{~s}^{-1}$

Published by Copernicus GmbH on behalf of the European Geosciences Union. 
(83-200 umol $\mathrm{m}^{-2} \mathrm{day}^{-1}$ ) and above river plumes they might increase even further, up to $5.44 \mathrm{nmol} \mathrm{m}^{-2} \mathrm{~s}^{-1}$ $\left(470\right.$ umol m$^{-2}$ day $\left.^{-1}\right)$.

To derive these fluxes, Amouroux et al. (2002) and Schmale et al. (2005) used the Liss and Merlivat (1986) and the Wanninkhof (1992) parameterisations of the dependency of the transfer velocity $k$ on wind speed $u$, hereafter referred to as LM86 and W92, respectively. Both parameterisations are quadratic or near-quadratic; W92, for example, parameterises $k$ as a function of $u$ as $\mathrm{k}=0.31 \mathrm{u}_{10}^{2}\left(\mathrm{~S}_{c} / 660\right)^{-0.5}$, where $S_{c}$ is the Schmidt number of $\mathrm{CO}_{2}$ in seawater, 660 is the $S_{c}$ for $\mathrm{CO}_{2}$ in seawater at $20^{\circ} \mathrm{C}$ and $u_{10}$ is the wind speed corrected to $10 \mathrm{~m}$ height under neutral conditions.

Recent work, based to a large extent on measurements performed during the GasEx-1998 field experiments (McGillis et al., 2004), has resulted in other, cubic parameterisations, which yield better fits to the data (e.g. Hare et al., 2004 and references therein). Wanninkhof and McGillis (1999), using recent laboratory and field studies, proposed a cubic relationship between air-sea gas exchange and wind speed, $\mathrm{k}_{660}=0.028 \mathrm{u}_{10}^{3}$, or $\left.\mathrm{k}=0.0283 \mathrm{u}_{10}^{3}\left(\mathrm{~S}_{c} / 660\right)^{-0.5}\right)$, which, compared with previous calculations using the W92 parameterisation, resulted in a significant increase of the calculated oceanic global annual $\mathrm{CO}_{2}$ uptake. Fairall et al. (2000) reviewed the theoretical basis of various parameterisation schemes for bulk-to-bulk gas transfer. Since then, McGillis et al. (2001) used eddy accumulation for $\mathrm{CO}_{2}$ to determine $k$ and showed that $k$ can be described in their study as $\mathrm{k}_{660}=3.3+0.026 \mathrm{u}_{10}^{3}$, where $k_{660}$ is the $k$ normalised to $S_{c}$ of $660 \mathrm{~cm} \mathrm{~h}^{-1}$ (which equals the $S_{c}$ for $\mathrm{CO}_{2}$ in seawater at $20^{\circ} \mathrm{C}$ ). Other recent work used measurements of dual tracers during the Southern Ocean Iron Fertilisation Experiment SOFex (Wanninkhof et al., 2004) addressing the discrepancies between observational and model-based estimates of $\mathrm{CO}_{2}$ uptake in the Southern Ocean (see also Feely et al., 2004). Work on the same experiment also considered the effect of wind speed products (Olsen et al., 2005) and addressed the effects of sea-state dependent wave breaking (Woolf, 2005).

In the present study, we applied the LM86, the W92 and additionally, the more recent parameterisation of McGillis et al. (2001), (hereafter referred to as MG01) to cruise data, so as to determine the flux of methane from the Black Sea to the atmosphere.

\section{Experiment and methods}

The BIGBLACK cruise took place in the waters of the Western Black Sea, in the longitude range $29-32^{\circ} \mathrm{E}$ and the latitude range $42-45.5^{\circ} \mathrm{N}$, onboard the Russian R/V "Professor Vodianitskiy".

Methane in air and seawater was measured with an automated Shimadzu GC/FID equipped with a Weiss equilibrator (Weiss, 1981). Details on the experimental setup can be found in Bange (1994) and Bange et al. (1994), while more details on the function of the equilibrator, as well as a mathematical treatment of the equilibrating processes can be found in Butler et al. $(1988,1989)$. Briefly, the analysis was performed isothermally on a mol sieve $5 \AA$ column at $50^{\circ} \mathrm{C}$, with an injector temperature of $60^{\circ} \mathrm{C}$ and a detector temperature of $280^{\circ} \mathrm{C}$. A 10 -port valve with two sample loops was used to inject the sample, which was dried before entering the analytical system by means of a $30-\mathrm{cm}$ glass tube filled with Sicapent drying agent. Sampling alternated between ambient air and equilibrated air. Two $\mathrm{CH}_{4}$ standards from MesserGriesheim (of 1.57 and $1.96 \mathrm{ppmv}$ methane) were used to calibrate the system during the cruise. Eight duplicate readings from alternate analyses of the two standards gave a response ratio of $1.244 \pm 0.012(1 \sigma)$, practically identical to the nominal manufacturer's concentration ratio of 1.248. Hence,

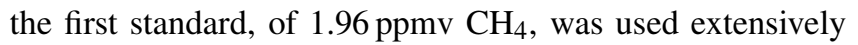
throughout the cruise (two to five calibrations daily), while the second one, of 1.57 ppmv $\mathrm{CH}_{4}$ was used only during the 17 December, 1999. The reproducibility of the measurements, as determined from multiple standard injections during the course of each day, was around $1 \%$.

The inlet for air analyses was around $50 \mathrm{~m}$ long, while the inlet from the equilibrated air was around $4 \mathrm{~m}$ long. Multiple runs under operating conditions with the $1.96 \mathrm{ppmv}$ methane standard connected to both inlets showed no significant differences that might have risen from inlet wall losses between the two inlets (i.e. the differences were within the $1 \%$ reproducibility limits).

The duplicate readings from two different sample loops provided us with the confidence that the precision to see significant local increases in atmospheric concentrations due to high methane fluxes was more than adequate. Methane supersaturations and fluxes were calculated from measurements using the methodology described in detail in Bange (1994) and Bange et al. (1994, 1996), which is based on the approach of Liss and Merlivat, 1986 (LM86), for the transfer velocity calculation. As noted in the Introduction, fluxes were also calculated with the W92 and the MG01 parameterisations.

We note here that LM86, W92 and MG01 normalise their parameterisations with respect to the $S_{c}$ of $\mathrm{CO}_{2}$ in seawater at $20^{\circ} \mathrm{C}$. Schmidt numbers for methane and $\mathrm{CO}_{2}$ are rather similar, their difference being $-1.7 \%$ to $2.6 \%$ in the temperature range $0^{\circ} \mathrm{C}$ to $20^{\circ} \mathrm{C}$. Hence LM86, W92 and MG01 parameterisations can be used for methane without modification and without introducing a significant error, since the uncertainty in $S_{c}$ ranges from $3 \%$ to $10 \%$, mainly due to uncertainties in the diffusion coefficient. We note also here that while LM86 note 600 as the $S_{c}$ of $\mathrm{CO}_{2}$ at $20^{\circ} \mathrm{C}$, W92 and MG01 note 660 as the $S_{c}$ of $\mathrm{CO}_{2}$ at $20^{\circ} \mathrm{C}$. However, $k$ being a function of either $\left(\mathrm{S}_{c} / 600\right)^{-0.5}$ or $\left(\mathrm{S}_{c} / 660\right)^{-0.5}$ (Watson et al., 1991, and references therein), the error from this convention is less than $5 \%$. 

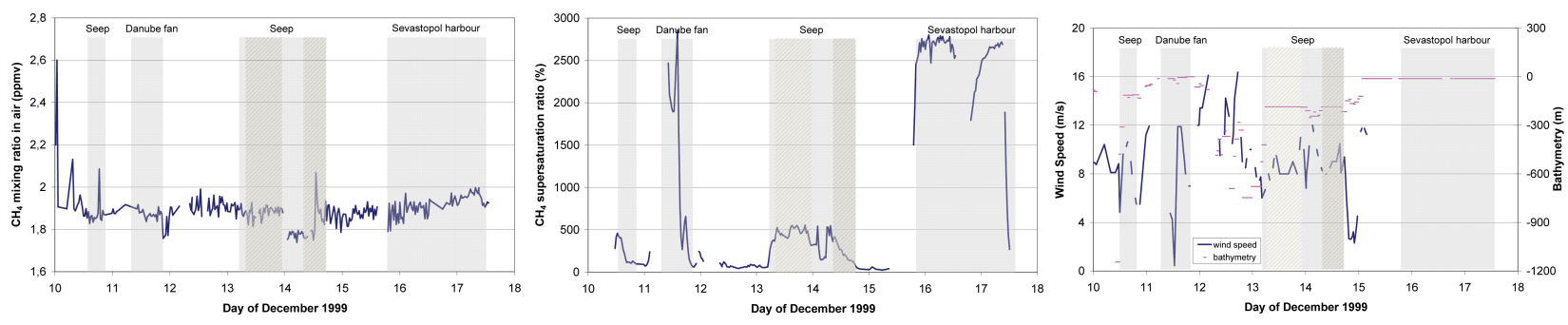

Fig. 1. Methane mixing ratios in air (left) and supersaturation ratios (middle) during the BIGBLACK cruise. Wind speed measurements and bathymetry time series are also plotted (right). Shaded areas denote ship's location, while areas with darker shading indicate measurements where the vessel was anchored directly above active seeps. Areas denoted "Seep" are areas with active seeps.

Water temperature and salinity at $4 \mathrm{~m}$ (the depth where the water pump inlet was located) were measured with CTD sondes during the cruise. The deviations $(1 \sigma)$ of these two parameters during the cruise were small (temperature: $10.68 \pm 0.29$, salinity $17.6 \pm 0.34$ ), hence their mean values were used in all calculations. Two pressure-equilibrating tubing lines in the equilibrator ensured sampling under atmospheric pressure, hence no pressure correction had to be applied.

We also established that the equilibration time of the seawater equilibrator (around $15 \mathrm{~min}$ ) might have caused, in the case of rapidly fluctuating concentrations, a smoothing of the measured seawater concentrations while sampling en route. This does not affect the measurements performed at the stations visited during the cruise (active seep areas and Sevastopol harbour). Furthermore, the system performed without any problems for the duration of the cruise and we were able to calculate supersaturation ratios and fluxes of methane from the cruise area to the atmosphere.

Wind measurements were made with the ship anemometer, at $10.78 \mathrm{~m}$ height ASL, on a ship mast of $4.75 \mathrm{~m}$ height, hence eliminating the need for corrections of the wind speed $u$ to $u_{10}$. These data were provided by the ship operator, and consist of measurements of wind speed and direction provided twice an hour. No details on the averaging times were provided. The data were corrected for ship's movement, based on concurrent data on ship's velocity and heading. Clearly, no such correction was applied for the times the ship was anchored.

The model used for calculating the dispersion of the methane plume from mud volcano eruptions is the 3-D airshed model ISC-AERMOD from Lakes Environmental Inc. (The et al., 2002), modified to accommodate a larger grid (original grid $50 \mathrm{~km} \times 50 \mathrm{~km}$ ). The model calculated the concentrations at $100 \times 100$ grid point receptors. It is a steadystate Gaussian plume dispersion model, based on U.S. Environmental Protection Agency's ISCST3 model (EPA, 1995). It calculates ground-level and aloft inert ambient pollutant concentrations and deposition fluxes, for continuous and/or accidental releases (per hour). The model can handle mul- tiple sources including point, volume, area, open pit as well as line source types. Source emission rates can be treated as constant or may be varied by month, season, hour-ofday, or other optional periods of variation. These variable emission rate factors may be specified for a single source or for a group of sources. In addition, the underlying ISCST3 model includes several options for addressing complicated problems like site-specific wind profile exponents, vertical potential temperature gradients, time-dependent exponential decay of emissions, plume rise calculated as a function of downwind distance, etc.

Required inputs are the wind velocity (see below for the wind velocity used for the three simulated atmospheric stability classes) and direction (various), relative humidity $(60 \%)$, temperature $(288 \mathrm{~K})$, pressure $(1024 \mathrm{mb})$ and atmospheric stability class (D-neutral, F-stable and A-unstable). The mixing height was set to $1000 \mathrm{~m}$.

\section{Results and discussion}

The determined concentrations of methane in air and seawater, the calculated super-saturation ratios, as well as wind speed measurements and bathymetry time series are presented in Figs. 1 and 2. The ship left the harbour of Istanbul on the 9 December 1999. Very high values of methane in air equilibrated with seawater lead to the saturation of the FID detector of the analytical system, hence inhibiting quantitative determination of the very high methane seawater supersaturations while in the harbour. Further, upon departure of the ship, the propeller caused sediment to enter the system; hence the measurements were resumed, after extensive cleaning, on the 10 December. On the 10 December, the ship sampled in open waters, over an active seep area, and over shelf waters. On the 11, the Danube fan area was sampled. On the 13 and the 14, a large part of the time was spent performing stations above active seep areas. The ship arrived outside the port of Sevastopol in the night of the 15 and remained anchored there before entering the port of Sevastopol early in the morning of the 16 , where measurements continued until the afternoon of the 17. 

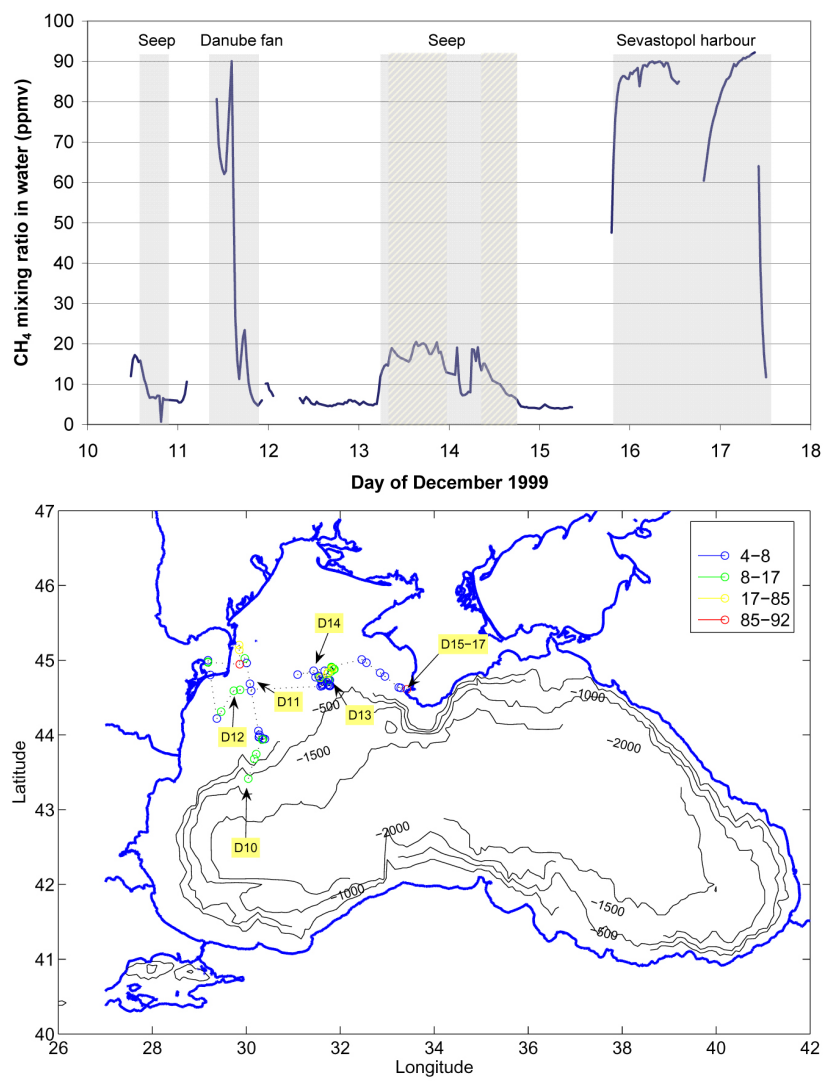

Fig. 2. Methane mixing ratios in water (in ppmv) during the BIGBLACK cruise plotted as a function of date (above) and as a function of position (below). The 1:250 000 resolution coastline is from NOAA's National Geophysical Data Centre. Shaded areas are as in Fig. 1. The arrows in the bottom figure denote the date (day of December, 00:00 h). Bathymetry contours are also shown (bottom, in metres).

The wind velocity during the cruise varied mostly between 6 and $10 \mathrm{~m} \mathrm{~s}^{-1}$, while on occasions it fell below $6 \mathrm{~m} \mathrm{~s}^{-1}$ or rose above $10 \mathrm{~m} \mathrm{~s}^{-1}$ (Fig. 1, right). The depth varied between $10 \mathrm{~m}$ and $1100 \mathrm{~m}$ (Fig. 1, right), while the mixed layer depth, as determined from CTD measurements during the cruise, was generally between 20 and $50 \mathrm{~m}$.

Above the two active seep areas where the ship sampled on the 10 and almost the entire 13 and 14 December, methane concentrations in seawater were 8-20 ppmv, resulting in super-saturation ratios $100-550 \%$. In the Danube fan area, where the ship sampled on the 11 December, methane concentrations in seawater were up to 90 ppmv, resulting in super-saturation ratios of up to nearly $3000 \%$, many times higher than in the active seep areas. These high concentrations are the result of the nutrient discharge from the Danube river, the nutrients coming from agricultural fertiliser applications within the river basin and settlement effluent along the river course.

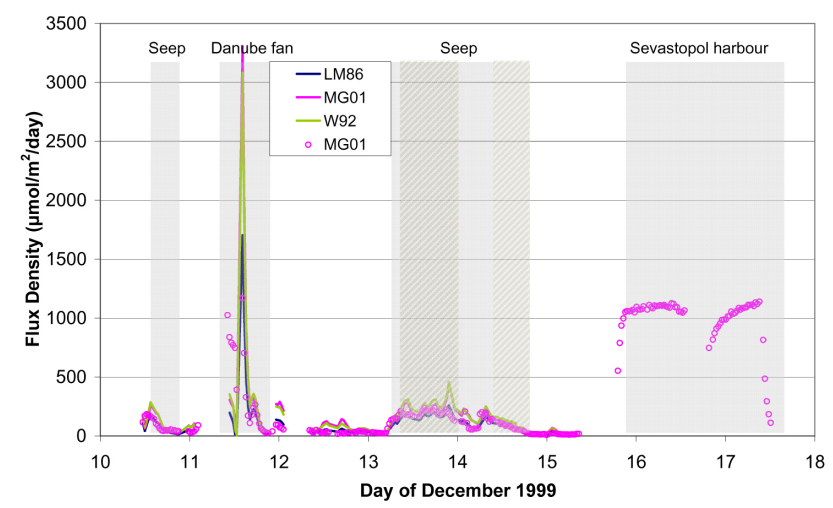

Fig. 3. Flux densities calculated after LM86, W92 and MG01 using the measured wind speed (lines). Dots are calculations after MG01 using the climatic wind speed value of $8 \mathrm{~m} / \mathrm{s}$. Shaded areas are as in Fig. 1.

In the port of Sevastopol, where the ship sampled from the end of the 15 until the 17 December, methane concentrations in seawater were up to $92 \mathrm{ppmv}$, resulting in super-saturation ratios of up to nearly $3000 \%$, also many times higher than in the active seep areas. The high concentrations in the ports of Sevastopol and Istanbul are indicative of high nutrient and organic load in the sediments, probably because of urban sewage effluent. Measurements were also obtained during stations directly above active seeps (Figs. 1 and 2). The measurements during the stations were made on two occasions, the 13 December from 08:00 to 20:05 and the 14 December from 08:10 to 17:30, while the vessel was anchored at a depth of around $180 \mathrm{~m}$. While during the first station the $\mathrm{CH}_{4}$ concentration in water did not vary much (15-21 ppmv), during the second one there were variations of a factor of two (7$15 \mathrm{ppmv})$. While it appears that in the former case the plume of dissolved methane was more uniform, in the latter one this was not the case. Heterogeneity in the near-field dissolved methane plume has been observed earlier (Clark et al., 2000), although at distances larger than the ones in our case, and hence on the second station measurements might have been influenced either by changing currents or the ship's drifting around the anchor, or both.

Flux densities (Fig. 3), as already mentioned, were calculated using the methodology described in detail in Bange (1994) and Bange et al. (1994), using the parameterisations of the dependency of the transfer velocity on wind speed of LM86, W92 and MG01 (see Introduction), and the measured wind speed. Flux densities were also calculated using the latest parameterisation, MG01, and the climatic value of wind speed for December, $8 \mathrm{~m} \mathrm{~s}^{-1}$ (Sorokin, 2002; NEMOC, 2006). Lacking wind speed measurements during the ship's stay in the port of Sevastopol, flux densities with actual wind speeds were not calculated, but they should probably be higher than above active seeps, as the flux calculations with the climatic value of wind speed, $8 \mathrm{~m} \mathrm{~s}^{-1}$, also shows. 
Quite high flux densities were also calculated for the Danube fan area. Generally, flux densities are higher than the ones obtained in our group's cruise in the same area during July 1995 (Amouroux et al., 2002) and also higher than the values reported by Schmale et al. (2005), obtained during MayJune 2003. In open and shelf waters, Amouroux et al. (2002) measured flux densities of 50-53 umol m${ }^{-2}$ day $^{-1}$, Schmale et al. (2005) measured $49 \mathrm{umol} \mathrm{m}^{-2}$ day $^{-1}$ (calculated with W92), while the measurements reported here range between 22-260 umol m${ }^{-2}$ day $^{-1}$ (calculated also with W92) for open and shelf waters. A part of the difference might be explained by lower wind speeds during the Amouroux et al. (2002) study, the climatic value for July being $5 \mathrm{~m} \mathrm{~s}^{-1}$ as compared with $8 \mathrm{~m} \mathrm{~s}^{-1}$ for December (Sorokin, 2002; NEMOC, 2006), and the exceptionally low wind speeds during the Schmale et al. (2005) measurements $\left(1.16 \mathrm{~m} \mathrm{~s}^{-1}\right)$. Fluxes during the present study above active seep areas during the 10, the 13 and the 14 December were up to $480 \mathrm{umol} \mathrm{m}^{-2}$ day $^{-1}$ and measurements at the Danube fan on the 11 December were up to $3150 \mathrm{umol} \mathrm{m}^{-2} \mathrm{day}^{-1}$ (W92). At the high wind speeds of the 11 and the 12 December (up to $16 \mathrm{~m} \mathrm{~s}^{-1}$ ), differences are observed between the cubic (LM86) and the quadratic parameterisations (MG01 and W92), the latter increasing the calculated wind densities by approximately a factor of two (Fig. 3), while at low wind speeds substantial differences (up to a factor of two) result also between MG01 and W92, the former being higher. Flux calculations with MG01 were performed also for the climatic value of wind speed, $8 \mathrm{~m} \mathrm{~s}^{-1}$ and are also presented in Fig. 3. Generally, since the mean wind during the campaign was near the climatic value, the differences in the flux calculations are not very big when the climatic wind speed value is used, except for the cases where the wind deviated significantly from the climatic value.

We used a simple method to estimate the effects of the above fluxes on the atmospheric concentrations of $\mathrm{CH}_{4}$ : We assume a box located above the sea, with its ceiling at $1000 \mathrm{~m}$, which appears a reasonable assumption for the height of the mixing atmospheric layer. The box is ventilated by the horizontal wind, for which we use the values that were measured during the BIGBLACK cruise onboard R/V "Professor Vodianitskiy" (as measured with the LM86 parameterisation, climatic value of $8 \mathrm{~m} \mathrm{~s}^{-1}$ with the MG01 parameterisation). If we assume that methane is vented into the box with the flux densities of Fig. 3 (LM86 and MG01), and the contents of the box are vented completely out of the box in the time required for the mean wind speed to cross the box from one side to the other, with a series of simple calculations we derive that the measured flux densities would result in an increase in the atmospheric mixing ratio of methane by the amounts given in Fig. 4, which do not exceed a few tens parts per trillion per volume (pptv). Clearly, under normal conditions the air-sea exchange of methane from the Black Sea has a negligible impact on the regional atmospheric background of methane, being many times smaller than the observed variability of atmospheric methane (Fig. 1a).

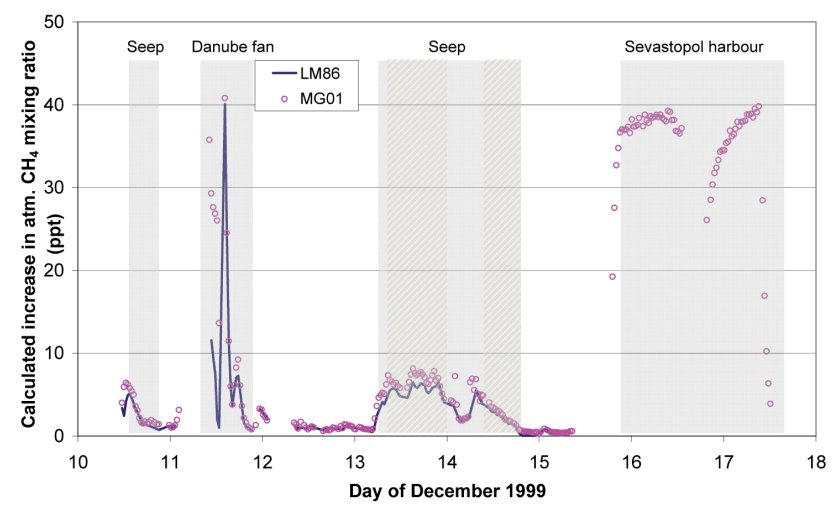

Fig. 4. Calculated increases (in parts per trillion per volume) in the atmospheric methane concentration due to the measured fluxes (using the LM86 parameterisation with measured wind speeds and the MG01 parameterisation with the climatic wind speed value). Shaded areas are as in Fig. 1. See also text.

\subsection{Eruption scenarios}

We note here that even the most intensive Black Sea bubble seep that was studied within the BIGBLACK and CRIMEA projects does not transfer methane into the atmosphere through bubble transport, which would be a more efficient means than dissolved methane for transferring methane to the atmosphere. Only at depths shallower than $90 \mathrm{~m}$ can some of the methane survive in the bubbles to reach the atmosphere, but this is probably very minor (McGinnis et al., 2006). At greater depths, all methane is dissolved from the bubbles long before they reach the surface. The same holds true for mud volcanoes at about $2080 \mathrm{~m}$ depth that were monitored during the CRIMEA project. During simultaneous eruptions from three mud volcanoes, the bubbles could be observed on the echo sounder rising $1300 \mathrm{~m}$ in the water column (Greinert et al., 2006; McGinnis et al., 2006). Therefore, in order for a significant methane input into the atmosphere to occur, a much more massive outgassing is needed. This seems rather unlikely for the shallower seep areas (100-600 m) given the diffuse nature of the seeping process. However, it does not seem impossible for a significant mud volcano eruption to generate a much larger methane bubble flux, with bigger bubbles and possibly even creating a bubble plume, which could eventually make it up to the atmosphere. We now examine the case of episodic outbursts due to mud volcano eruptions. We assume underwater eruptions, where a portion of the emitted methane rises all the way from the sea floor to the sea surface, passes the pycnocline and then is released to the atmosphere. We assume the release to the atmosphere occurs from a square area source $100 \mathrm{~m} \times 100 \mathrm{~m}$. Several authors report self-ignition of the expelled gas from mud volcanoes (Aliyev et al., 2002; Bagirov et al., 1996a, b; Jevanshir, 2002; Kugler, 1939), even for underwater eruptions (Sokolov, 1969). However, whether self-ignition is common 
(a)
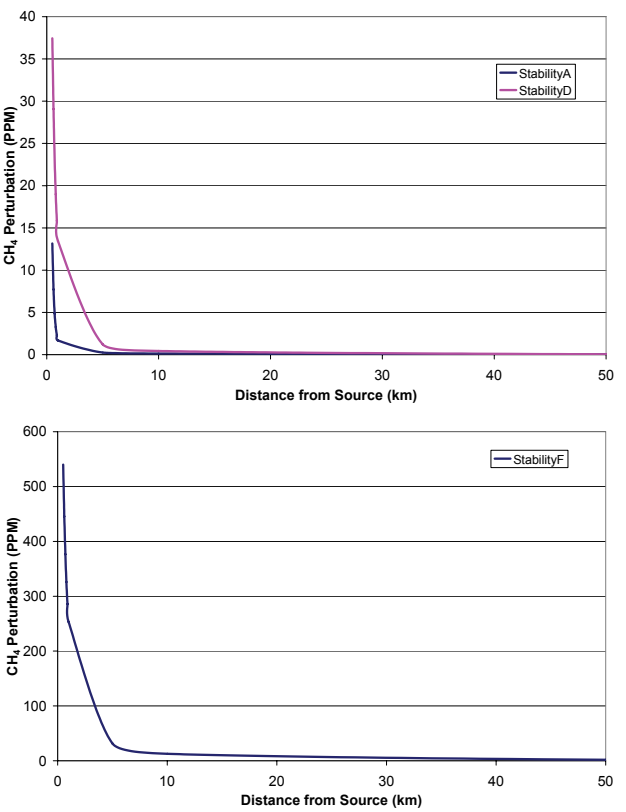

(b)

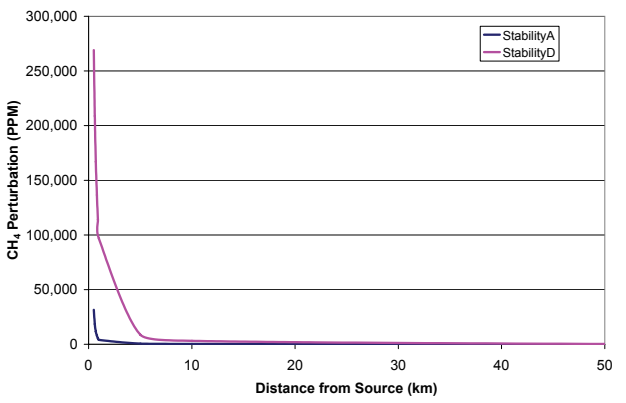

(c)

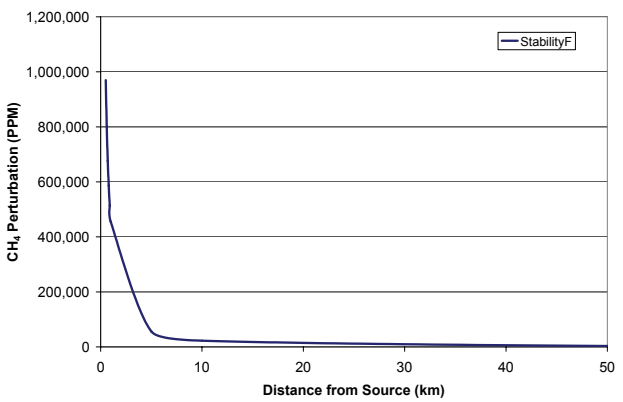

(d)

Fig. 5. Calculated increases in the atmospheric background of methane for two cases of unignited eruptions under different atmospheric conditions. (a) and (b): An underwater eruption of 22.5 million $\mathrm{m}^{3}$ methane at shallow depths, with $0.09 \%$ of the emitted methane reaching the surface, is assumed (see text). The wind speed used in the calculations was $3 \mathrm{~m} \mathrm{~s}^{-1}, 8 \mathrm{~m} \mathrm{~s}^{-1}$ and $12 \mathrm{~m} \mathrm{~s}^{-1}$, for stability classes A and D (a) and F (b), respectively. (c) and (d): An underwater eruption of 323 million $\mathrm{m}^{3}$ methane at $2 \mathrm{~km}$ depth, with $30 \%$ of the emitted methane reaching the surface, half of it in gaseous form within the bubbles, is assumed (see text). The wind speed used in the calculations was $3 \mathrm{~m} \mathrm{~s}^{-1}, 8 \mathrm{~m} \mathrm{~s}^{-1}$ and $12 \mathrm{~m} \mathrm{~s}^{-1}$, for stability classes A and D (c) and F (d), respectively. in underwater eruptions and under which circumstances it might occur in nature, are, to our knowledge, not well documented, hence no simulations for ignited emission were performed. Two eruption scenarios are examined. In both cases, we assume the eruptions last for $4 \mathrm{~h}$, and underwater emission rates are taken from Guliev (1992). Guliev (1992), p. 7, quoted extensively in the western peer-reviewed literature (e.g. in Kopf, 2002) and Guliyiev and Feizullayev (1994), also quoted extensively (e.g. in Dimitrov, 2002), state that for four prominent mud volcano eruptions in Azerbaijan between 1902-1961 (on land), the amount of gas expelled during the first few hours ranged from 22.5-495 million $\mathrm{m}^{3}$. We note here that Guliev (1992) has performed the only extensive study on quantitative eruptive methane emissions from mud volcanoes; apart from this study, only sporadic data are published. However, these infrequent data (summarized in Dimitrov, 2002) yield estimates of methane expelled during the eruptive phase that range from 210 million $\mathrm{m}^{3}$ to 40 billion $\mathrm{m}^{3} \mathrm{CH}_{4}$ over 1-2 days. Hence for the simulations presented here two cases were modelled, one eruption near the lower end of Guliev's (1992) estimates, and one near the upper end.

The first case presents a set of simulations for different atmospheric conditions for a small underwater eruption of 22.5 million $\mathrm{m}^{3}$ methane, occurring at shallow depths, where an estimated $0.09 \%$ of the methane reaches the atmosphere. The second case presents a set of simulations for different atmospheric conditions for a large underwater eruption of 323 million $\mathrm{m}^{3}$ methane, occurring at a depth of $2 \mathrm{~km}$, where an estimated $30 \%$ of the methane reaches the atmosphere. More details on the simulations and the assumptions involved are given below. For both cases, the fraction of methane that reaches the air-sea interface was estimated using the bubble model of McGinnis et al. (2006) in combination with the modified (for deep water conditions) bubble plume model of Wüest et al. (1992).

In the first case, a small underwater eruption of 22.5 million $\mathrm{m}^{3}$ methane (at the lower end of Guliev, 1992) is simulated. Following results from recent work on bubble-water column exchange of gases in the frame of the CRIMEA project (McGinnis et al., 2006), it appears that for such small emission rates, the eruption has to occur at relatively shallow depths, for even a small fraction of the methane to reach the surface. These results show that in the worst case $0.09 \%$ of the methane gas might reach the atmosphere. We assume the release to the atmosphere occurs from a rectangular area source $100 \mathrm{~m} \times 100 \mathrm{~m}$, hence the emission rate in this case is $6.25 \mathrm{mmol} \mathrm{m}^{-2} \mathrm{~s}^{-1}$ (or $1000 \mathrm{~g} \mathrm{~s}^{-1}$ ).

These modelling results (Figs. 5a, b) suggest that even relatively small methane outbursts from mud volcanism may result in very large enhancements in the regional methane concentrations near the sea surface. For unstable and neutral conditions, the release results in raising the atmospheric methane concentration by $1-40 \mathrm{ppmv}$ in the first $5 \mathrm{~km}$ downwind from the release site, falling off at greater distances. 
Under nighttime stable conditions (Fig. 5b), the enhancement can reach 600 ppmv close to the source, creating smog chamber conditions. The larger computed increases propagate also at larger distances (for $30 \mathrm{~km}$ downwind methane is increased by more than $7 \mathrm{ppmv}$, falling to its atmospheric mixing ratio of $1.8 \mathrm{ppmv}$ after $50 \mathrm{~km}$ ). Given that the dispersion model is linear (i.e. a doubling of the emission rate will double the concentrations), if a larger proportion of the methane reaches the atmosphere, concentrations will be proportionally larger.

In the second case, a massive underwater eruption of 323 million $\mathrm{m}^{3}$ methane (near the upper end of Guliev, 1992), occurring at a depth of $2 \mathrm{~km}$, is simulated. This translates to $16000000 \mathrm{~g} \mathrm{~s}^{-1}$. The amounts of methane that might rise to the sea/atmosphere interface from such a massive methane release at $2 \mathrm{~km}$ depth have been estimated in the frame of the CRIMEA project. The initial conditions of the bubble model assume an initial plume radius of $100 \mathrm{~m}$ and a bubble diameter of $8 \mathrm{~mm}$. The model has been run for various emission rates; it appears that $16000000 \mathrm{~g} \mathrm{~s}^{-1}$ is near the minimum emission rate required for copious amounts of the methane to reach the surface from $2 \mathrm{~km}$ depth. At this emission rate, roughly $30 \%$ of the methane reaches the atmosphere in both gaseous and dissolved form (about 50\% in bubbles and $50 \%$ dissolved), while at emission rates of $1600000 \mathrm{~g} \mathrm{~s}^{-1}$ no methane reaches the surface. On the other hand, simulating a mud volcano gas release of $24500000 \mathrm{~g} \mathrm{~s}^{-1}$ (i.e. 495 million $\mathrm{m}^{3}$, the upper end of emission rates given by Guliev, 1992) at $2 \mathrm{~km}$ depth, all of the methane reaches the surface (about 20\% in bubbles and $80 \%$ dissolved). These simulations assume that a hydrate skin exists on the bubble in the stability zone (see, e.g., McGinnis et al., 2006; Rehder et al., 2002; Sauter et al., 2006). If no hydrate skin exists on the bubble, then the plume does not reach the surface. As mentioned above, bubble modelling estimates that $30 \%$ of the emitted gas reaches the atmosphere, about $50 \%$ of the methane residing in the bubbles and about 50\% dissolved. The plume water when it reaches the surface is denser, so it is difficult to estimate with certainty how much the dissolved fraction will degass before settling back to the equilibrium depth. Hence for the atmospheric dispersion modelling we assume that the direct bubble transfer is more efficient than the diffusion of dissolved methane, and neglect the latter in the calculation of emission rates to the atmosphere, arriving at an equivalent emission rate to the atmosphere of $15 \mathrm{~mol} \mathrm{~m}^{-2} \mathrm{~s}^{-1}$, or $2400 \mathrm{~kg} \mathrm{~s}^{-1}$. Assuming the release takes place from an area source $100 \mathrm{~m} \times 100 \mathrm{~m}$, the maximum increases in the atmospheric levels of methane during the 4-h constant rate eruption as estimated through dispersion modelling with ISC-AERMOD, are given in Figs. 5c, d.

The plume dispersion modelling results for the second case (i.e. a 323 million $\mathrm{m}^{3}$ methane eruption at $2 \mathrm{~km}$ depth) show that the spatial average of the methane perturbation (i.e. the increase above the background levels) during the eruption over a square receptor area with dimen- sion $100 \mathrm{~km} \times 100 \mathrm{~km}$ centred in the source (assuming a 4hour release) is approximately 4 ppmv for unstable conditions (A), $10 \mathrm{ppmv}$ for neutral conditions (D) and $20 \mathrm{ppmv}$ for stable conditions (F), which represent increases of the average background methane mixing ratio of $1.86 \mathrm{ppmv}$ over the Black Sea of $315 \%, 640 \%$ and $1175 \%$, respectively.

\subsection{Considerations for remote sensing detection}

Assuming that the concentrations of methane above the mixing height remain unaffected at $1.86 \mathrm{ppmv}$, a tropopause height of $10 \mathrm{~km}$ and negligible methane concentrations above the tropopause, these correspond to columnar increases of atmospheric methane of $146 \%, 216 \%$, and $331 \%$ for these three stability classes, respectively.

Similarly, the spatial 24-h average of the methane perturbation over a square receptor area with dimension $100 \mathrm{~km} \times 100 \mathrm{~km}$ centred in the source (also assuming a 4$\mathrm{h}$ release) is approximately $0.7 \mathrm{ppm}$ for unstable conditions (A), $2.7 \mathrm{ppm}$ for neutral conditions (D) and $6.5 \mathrm{ppm}$ for stable conditions (F). The wind velocity field was 3,8 and $12(\mathrm{~m} / \mathrm{s})$ for the stability classes A, D and F, respectively (the perturbation amount will be generally higher for lighter winds). Hence, given an average background methane mixing ratio of $1.86 \mathrm{ppmv}$ over the Black Sea, the calculated increase of the 24-h average mixing ratio of methane over the $100 \mathrm{~km} \times 100 \mathrm{~km}$ area ranges from $35 \%$ for unstable conditions to $350 \%$ for stable conditions. Again, these correspond to 24-h average columnar increases of atmospheric methane of $108 \%, 131 \%$, and $175 \%$ for the three simulated stability classes A, D and F, respectively.

Clearly, these perturbations of the columnar amounts over the eruption time $(4 \mathrm{~h})$ and over the next $24 \mathrm{~h}$ following the eruption are fairly larger than the few percent perturbations required for the detection of emissions by space-borne instrumentation such as the SCIAMACHY instrument onboard ENVISAT.

Given the steady improvement of algorithms for the detection of methane from space (e.g. Buchwitz et al., 2000, 2005; Meirink et al., 2006) we would argue here that the detection of either fairly large underwater mud volcano eruptions or modest ones over land might be possible with available space-borne instrumentation, providing perhaps a means for remote sensing of mud volcano eruptions. Generally, the typical spatial resolution of the SCIAMACHY instrument onboard ENVISAT is $30 \mathrm{~km}$ by $60 \mathrm{~km}$. Each horizontal scan of the atmosphere in limb covers $960 \mathrm{~km}$ in the horizontal (across track direction), and global coverage is achieved after 6 days (Bovensmann et al., 1999). SCIAMACHY consists of eight main spectral channels and seven spectrally broad band Polarization Measurement Devices (PMDs) (details are given in Bovensmann et al., 1999). Observations of channel 8 (from a small spectral fitting window $2265-2280 \mathrm{~nm}$ ) and PMD number $1(320-380 \mathrm{~nm})$ have been used in the detection of $\mathrm{CH}_{4}$ (Buchwitz et al., 2000, 2005). Channel 8 spectral 
resolution is $0.2 \mathrm{~nm}$. For SCIAMACHY the spatial resolution, i.e., the footprint size of a single nadir measurement, depends on the spectral interval and orbital position. For channel 8 the spatial resolution is $30 \mathrm{~km} \times 120 \mathrm{~km}$ corresponding to an integration time of $0.5 \mathrm{~s}$, except at high solar zenith angles, where the pixel size is twice as large $(30 \mathrm{~km} \times 240 \mathrm{~km})$. Using various bias corrections improved methane data products have been generated (e.g. Buchwitz et al., 2005); their comparison with model simulations shows agreement within a few percent (mostly within 5\%).

The main scientific application of the methane measurements of SCIAMACHY is to obtain information on the surface sources of methane (e.g. Frankenberg et al., 2005). The modulation of methane columns due to methane sources (other than mud volcano eruptions) is only on the order of a few percent and typically, the weak methane source signal is difficult to be clearly detected with single overpass SCIAMACHY data, unless the variations in atmospheric methane exceed a few percent. Applications of existing algorithms have shown that SCIAMACHY can detect elevated methane columns resulting from emissions from surface sources such as rice fields and wetlands over India, southeast Asia and central Africa (Buchwitz et al., 2005; Frankenberg et al., 2005).

Hence, considering also the modelling results of the present study, it appears that certain events of mud volcano eruptions are very well above the sensitivity of satellite instruments such as SCIAMACHY. It also appears that elevations in the columnar methane amounts following some of the eruptions would persist long enough over areas comparable with the satellite footprint. This means, given that global coverage is achieved with ENVISAT every 6 days, and that the elevations survive for about $24 \mathrm{~h}$ at detectable levels, that a fair fraction (perhaps 10-20\%) of the elevations in atmospheric concentrations caused by such massive events in a given region might survive until the next ENVISAT overpass. Although the present study neither offers a complete assessment for the extent of the applicability of satellite monitoring of mud volcano eruptions, nor fully constrains this, it offers nevertheless results that show that such an assessment study might prove very useful.

Further, very little is known about the size-frequency distribution of such eruptive events. Apart from Guliev (1992), Jakubov (1971) provides statistics for 32 eruptions in Eastern Azerbaijan considering that 122 eruptions have occurred during the period 1840-1967. Ali-Zade et al. (1984) state that 200 eruptions in 50 mud volcanoes have occurred in Eastern Azerbaijan from 1910 to 1980, while Ridd (1970) shows a time interval of 1-22 years for mud volcanoes in New Zealand. Dimitrov (2002) summarises these and other data to infer, "with great skepticism", as the author states, that about 30 mud volcanoes of Lokbatan type and 10 ones of the Schugin type erupt every year. Since it appears that at least certain events might be observable from space, a more thorough assessment of the possible range of events that might fall within the sensitivity limits of space-borne sensors and the possible fraction of the time that these events might occur within the observing satellite swath without obscuring interferences (e.g. clouds) might ultimately prove very useful not only in observing these events, but also in obtaining an idea, from space-borne observations, about the frequency-size distribution of such events.

Acknowledgements. The authors wish to thank the captain and crew of R/V "Professor Vodyanitskiy". Also, we would like to acknowledge the exchange of ideas with the partners of the BIGBLACK and CRIMEA projects. This work was funded under the BIGBLACK (EU IC15 CT96 0107) and CRIMEA (EVK-2-CT-2002-00162) European Commission projects.

Edited by: W. E. Asher

\section{References}

Aliyev, A., Guliev, I. S., and Belov, I. S: Catalogue of recorded eruptions of mud volcanoes of Azerbaijan, Nafta Press, Baku, 2002.

Ali-Zade, A., Shnyokov, E., Grigorianz, B., Aliev, A., and Rahmanov, R.: Geotectonic conditions of mud volcano manifestation on the Earth and their significance for oil and gas prospects (in Russian), Proc. 27th World Geol. Congr. C13, 166-172, 1984.

Amouroux, D., Roberts, G., Rapsomanikis, S., and Andreae, M. O.: Biogenic Gas $\left(\mathrm{CH}_{4}, \mathrm{~N}_{2} \mathrm{O}\right)$ Emission to the Atmosphere from Near-shore and Shelf Waters of the North Western Black Sea, Estuarine, Coastal Shelf Sci., 54(3), 575-587, 2002.

Bagirov, E., Nadirov, R., and Lerche, I.: Flaming eruptions and ejections from mud volcanoes in Azerbaijan: Statistical risk assessment from the historical records, Energy Explor. Exploit., 14, 535-583, 1996a.

Bagirov, E., Nadirov, R., and Lerche, I.: Earthquakes, mud volcano eruptions, and fracture formation hazards in the South Caspian basin: Statistical inferences from the historical record, Energy Explor. Exploit., 14, 585-606, 1996b.

Bange, H. W., Bartell, U. H., Rapsomanikis, S., and Andreae, M. O.: Methane in the Baltic and North Seas and a reassessment of marine emissions of methane, Global Biogeochem. Cycles, 8 , 465-480, 1994.

Bange, H. W.: Messungen von Lachgas $\left(\mathrm{N}_{2} \mathrm{O}\right)$ und Methan $\left(\mathrm{CH}_{4}\right)$ in Europaeischen Nebenmeeren, Ph.D. Thesis, Johannes Gutenberg-Universitaet, Mainz, 1994.

Bange, H. W., Rapsomanikis, S., and Andreae, M. O.: The Aegean Sea as source of atmospheric nitrous oxide and methane, Marine Chem., 53, 41-49, 1996.

Bovensmann, H., Burrows, J. P., Buchwitz, M., Frerick, J., Noël, S., Rozanov, V. V., Chance, K. V., and Goede, A. P. H.: SCIAMACHY- Mission Objectives and Measurement Modes, J. Atmos. Sci., 56, 127-149, 1999.

Buchwitz, M., Rozanov, V. V., and Burrows, J. P.: A near infrared optimized DOAS method for the fast global retrieval of atmospheric $\mathrm{CH} 4, \mathrm{CO}, \mathrm{CO} 2, \mathrm{H} 2 \mathrm{O}$, and $\mathrm{N} 2 \mathrm{O}$ total column amounts from SCIAMACHY/ENVISAT-1 nadir radiances, J. Geophys. Res., 105, 15 231-15 246, 2000.

Buchwitz, M., de Beek, R., Noel, S., Burrows, J. P., Bovensmann, H., Bremer, H., Bergamaschi, P., Koerner, S., and Heimann, 
M.: Carbon monoxide, methane and carbon dioxide columns retrieved from SCIAMACHY by WFM-DOAS: year 2003 initial data set, Atmos. Chem. Phys., 5, 3313-3329, 2005, http://www.atmos-chem-phys.net/5/3313/2005/.

Butler, J. H., Elkins, J. W., Brunson, C. M., Egan, K. B., Thompson, T. M., Conway, T. J., and Hall, B. D.: Trace gases in and over the West Pacific and East Indian Oceans during the El Nino-Southern Oscillation event of 1987, NOAA Data Report ERL ARL-16, Air Resources laboratory, Silver Spring, MD, USA, 1988.

Butler, J. H., Elkins, J. W., Thompson, T. M., and Egan, K. B.: Tropospheric and dissolved $\mathrm{N}_{2} \mathrm{O}$ off the West Pacific and Indian Oceans during the El Nino-Southern Oscillation event of 1987, J. Geophys. Res., 94, 14 865-14 877, 1989.

Clark, J. F., Washburn, L., Hornafius, J. S., and Luyendyk, B. P.: Dissolved hydrocarbon flux from natural marine seeps to the southern California Bight, J. Geophys. Res., 105, 11 509-11 522, 2000.

Cynar, F. J. and Yayanos, A. A.: Distribution of methane in the upper waters of Southern California Bight, J. Geophys. Res., 97, $11269-11285,1992$.

Dimitrov, L. I.: Mud volcanoes - the most important pathway for degassing deeply buried sediments, Earth-Sci. Rev., 59, 49-76, 2002.

Durisch-Kaiser, E., Klauser, L., Wehrli, B., and Schubert, C.: Evidence of intense archaeal and bacterial methanotrophic activity in the Black Sea water column, Appl. Environ. Microbiol., 71, 8099-8106, 2005.

EPA: User's Guide for the Industrial Source Complex (ISC3) Dispersion Models/ Volume I - User Instructions, US EPA, Office of Air Quality Planning and Standards, Emissions Monitoring and Analysis Division, Research Triangle Park, NC 27711. Report number EPA-454/B-95-003a, 1995.

Etiope, G. and Klusman, R. W.: Geologic emissions of methane to the atmosphere, Chemosphere, 49, 777-789, 2002.

Fairall, C. W., Hare, J. E., Edson, J. B., and McGillis, W.: Parameterisation and micrometeorological measurements of air-sea gas transfer, Boundary-Layer Meteorol., 96, 63-105, 2000.

Feely, R. A., Wanninkhof, R., McGillis, W., Karr, M.-E., and Cosca, C. E.: Effects of wind speed and gas exchange parameterisations on the air-sea $\mathrm{CO}_{2}$ fluxes in the equatorial Pacific Ocean, J. Geophys. Res., 109, C08S03, doi:10.1029/2003JC001896, 2004.

Frankenberg, C., Meirink, J. F., van Weele, M., Platt, U., and Wagner, T.: Assessing methane emissions from global spaceborne observations, Science, 308, 1010-1014, 2005.

Greinert, J., Artemov, Y., Egorov, Y., De Batist, M., and McGinnis, D.: 1300-m high rising bubbles from mud volcanoes at $2080 \mathrm{~m}$ in the Black Sea: Hydroacoustic characteristics and temporal variability, Earth Planet. Sci. Lett., 244, 1-15, 2006.

Guliev, I. S.: A review of mud volcanism, Report, 65 pp., Inst. of Geol., Azerbaijan Acad. of Sci., Baku, 1992.

Guliyiev, I. S. and Feizullayev, A. A.: Natural hydrocarbon seepages in Azerbaijan, Proc. AAPG Hedberg Research Conference, 24-28 April, Vancouver, Canada, 76-79, 1994.

Hare, J. E., Fairall, C. W., McGillis, W. R., Edson, J. B., Ward, B., and Wanninkhof, R.: Evaluation of the NOAA/CoupledOcean Atmopheric Response Experiment (NOAA/COARE) airgas tranfer parameterization using GasEx data, J. Geophys. Res., 109, C08S11, doi:10.1029/2003JC001831, 2004.

Hornafius, J. S., Quigley, D., and Luyendyk, B. P.: The world's most spectacular marine hydrocarbon seeps (Coal Oil Point, Santa Barbara Channel, California): quantification of emissions, J. Geophys. Res., 104, 20 703-20711, 1999.

IPCC, Climate Change 2001: Third Assessment - The Scientific Basis, IPCC, Geneva, Switzerland, 2001.

Jakubov, A. A., Ali-Zade, A. A., and Zeinalov, M. M.: Mud volcanoes of the Azerbaijan SSR: Atlas, Elm-Azerbaijan Acad. of Sci. Baku, 1971.

Jevanshir, R. D.: All about mud volcanoes, 97 pp., Inst. Of Geol., Azerbaijan Acad. of Sci., Baku, 2002.

Judd, A. G., Davies, G., Wilson, J., Holmes, R., Baron, G., and Bryden, I.: Contributions to atmospheric methane by natural seepages on the UK continental shelf, Marine Geol., 137, 427-455, 1997.

Klusman, R. W., Leopold, M. E., and LeRoy, M. P.: Seasonal variation in methane fluxes from sedimentary basins to the atmosphere: Results from chamber measurements and modelling of transport from deep sources, J. Geophys. Res., 105D, $24661-$ 24 670, 2000.

Kopf, A. J.: Significance of mud volcanism, Rev. Geophys., 40, 1005, doi:20.1029/2000RG000093, 2002.

Kugler, H. G.: Visit to Russian oil districts, J. Inst. Pet. Technol. Trinidad, 25(184), 68-88, 1939.

Kvenvolden, K. A.: Gas hydrates-Geological perspective and global change, Rev. Geophys., 31, 173-187, 1993.

Lelieveld, J., Crutzen, P. J., and Brühl, C.: Climate effects of atmospheric methane, Chemosphere, 26, 739-768, 1993.

Lelieveld, J., Crutzen, P., and Dentener, F. J.: Changing concentration, lifetime and climate forcing of atmospheric methane, Tellus, 50B, 128-150, 1998.

Liss, P. S. and Merlivat, L.: Air-sea exchange rates: introduction and synthesis, in The role of air-sea exchange in geochemical cycling, edited by: Buat-Menard, P., 113-127, Reidel, D., New York, 1986.

McGillis, W. R., Edson, J. B., Ware, J. D., Dacey, J. W. H., Hare, J. E., Fairall, C. W., and Wanninkhof, R.: Carbon dioxide flux techniques performed during GasEx-98, Mar. Chem., 75, 267280, 2001.

McGillis, W. R., Asher, W.E., Wanninkhof, R., Jessup, A.T., and Feely, R.A.: Introduction to special section: Air-sea exchange, J. Geophys. Res., 109, C08S01, doi:10.1029/2004JC002605, 2004.

McGinnis, D. F., Greinert, J., Artemov, Y., Beaubien, S. E., and Wüest, A.: Fate of rising methane bubbles in stratified waters: How much methane reaches the atmosphere?, J. Geophys. Res., 111, C09007, doi:10.1029/2005JC003183, 2006.

Meirink, J. F., Eskes, H. J., and Goede, A. P. H.: Sensitivity analysis of methane emissions derived from SCIAMACHY observations through inverse modelling, Atmos. Chem. Phys., 6, 1275-1292, 2006 , http://www.atmos-chem-phys.net/6/1275/2006/.

NEMOC: Naval European Meteorology and Oceanography Command, available online at https://www.nemoc.navy.mil/index. html, 2006.

Olsen, A., Wanninkhof, R., Trinanes, J. A., and Johannessen, T.: The effect of wind speed products and wind speed-gas exchange relationships on interannual variability of the air-sea $\mathrm{CO}_{2}$ gas transfer velocity, Tellus, 57B, 95-106, 2005.

Rehder, G., Brewer, P. W., Peltzer, E. T., and Friedrich, G.: Enhanced lifetime of methane bubble streams within 
the deep ocean, Geophys. Res. Lett., 29(15), 1731, doi:10.1029/2001GL013966, 2002.

Ridd, M. F.: Mud volcanoes in New Zealand, AAPG Bull., 54, 601616, 1970.

Sauter, E. J., Muyakshin, S. I., Charlou, J.-L., Schlueter, M., Boetius, A., Jerosch, K., Damm, E., Foucher, J.-P., and Klages, M.: Methane discharge from a deep-sea submarine mud volcano into the upper water column by gas hydrate-coated methane bubbles, Earth Planet. Sci. Lett., 243, 354-365, 2006.

Schmale, O., Greinert, J., and Rehder, G.: Methane emission from high-intensity marine gas seeps in the Black Sea into the atmosphere, Geophys. Res. Lett., 32, L07609, doi:10.1029/2004GL021138, 2005.

Sokolov, V., Buniat-Zade, Z., Geodekian, A., and Dadashev, F.: The origins of gases of mud volcanoes and the regularities of powerful eruptions, Advances in Organic Chemistry, Pergamon, Oxford, 473-484, 1969.

Sorokin, Y. I.: The Black Sea Ecology and Oceanography. Backhuys Publishers, Leiden, The Netherlands, 2002.

The, J. L., The, C., and Johnson, M.: ISC-AERMOD View User's Guide, Lakes Environmental Software, Lakes Environmental Inc., 2002.
Wanninkhof, R.: Relationship between wind speed and gas exchange over the ocean, J. Geophys. Res., 97(C5), 7373-7382, 1992.

Wanninkhof, R. and McGillis, W. R.: A cubic relationship between air-sea $\mathrm{CO}_{2}$ exchange and wind speed, Geophys. Res. Lett., 26, 1889-1892, 1999.

Wanninkhof, R., Sullivan, K. F., and Top, Z.: Air-sea gas tranfer in the Southern Ocean, J. Geophys. Res., 109, C08S19, doi:10.1029/2003JC001767, 2004.

Ward, B. B.: The subsurface methane maximum in the California Bight, Cont. Shelf Res., 12, 735-752, 1992.

Watson, A. J., Upstill-Goddard, R. C., and Liss, P. S.: Air-sea gas exchange in rough and stormy seas measured by a dual-tracer technique, Nature, 349, 45-147, 1991.

Weiss, R. F.: Determinations of carbon dioxide and methane by dual catalyst flame ionisation chromatography and nitrous oxide by electron capture chromatography, J. Chromatogr, Sci., 19, 611616, 1981.

Woolf, D. K.: Parametrization of gas transfer velocities and seastate-dependent wave breaking, Tellus, 57B, 87-94, 2005.

Wüest, A., Brooks, N., and Imboden, N.: Bubble Plume Modeling for Lake Restoration, Water Resour. Res., 28(12), 3235-3250., 1992. 